\title{
Parkinsonism and D-512, dopamine D2/3 receptor agonist; A
}

\section{review of literature}

\author{
Madeeha Subhan Waleed ${ }^{1 *}$, Waleed Sadiq ${ }^{2}$, Sannniyah Subhan $^{3}$ \\ ${ }^{1}$ Graduate, Ayub Medical College, Pakistan. \\ ${ }^{2}$ Resident Physician, Staten Island University Hospital, New York, NY, USA. \\ ${ }^{3}$ Oakton Community College, Chicago, IL, USA.
}

*Corresponding Author: Madeeha Subhan Waleed, Graduate, Ayub Medical College, Pakistan.

Received date: October 06, 2020; Accepted date: October 19, 2020; Published date: October 30, 2020

Citation: M S Waleed, W Sadiq, S Subhan. (2020) Parkinsonism and D-512, dopamine D2/3 receptor agonist; A review of literature. International Journal of Clinical Case Reports and Reviews. 4(1); DOI: 10.31579/2690-4861/077

Copyright: (C) 2020 Madeeha Subhan Waleed, This is an open-access article distributed under the terms of the Creative Commons Attribution License, which permits unrestricted use, distribution, and reproduction in any medium, provided the original author and source are credited.

\begin{abstract}
In 1817, James Parkinson first coined the term Paralysis Agitans (An Essay on the Shaking Palsy), Jean-Marie Charcot was the first to coin term Parkinson's disease (PD). Three most common and obvious symptoms in patients with PD are tremor, rigidity, and bradykinesia. A multidisciplinary team involving neurologists, primary care practitioners, nurses, physical therapists, social workers is used to diagnose PD. Nonpharmacological and pharmacological treatment is given to the patient. However, this disease demands more clinical translational and prognostic research, identifying biomarkers that can help in early diagnosis of the disease and on developing future disease-modifying interventions.

Keywords: parkinsonism; d-512, dopamine $\mathrm{d} 2 / 3$ receptor agonist
\end{abstract}

\section{Introduction:}

In 1817, James Parkinson first coined the term Paralysis Agitans (An Essay on the Shaking Palsy), Jean-Marie Charcot was the first to coin term Parkinson's disease (PD) [1]. PD can literally be termed as dopamine deficiency motor syndrome but non motor symptoms as malaise, weakness and increased sleep also occur. Levodopa a gold treatment for PD also targets the motor symptoms [2]. Non motor syndrome (NMS) refers to the non-motor symptoms occurring with PD. In 2000's NMS were studied and investigated [3]. NMS and its major impacts on quality of life in PD were thoroughly investigated and dire need for treatment schemes originated $[4,5]$ Braak et al. stated that pathophysiology of PD involves multiple neurotransmitters [6].It is proposed that it is a prion like process with alpha synuclein lewy body deposition [7]. PD is multi system multiple neurotransmitter involving process $[8,9]$.

\section{Incidence:}

In United Kingdom 1/60 people may develop Parkinsonism and the incidence increases with age $[10,11]$.

\section{Diagnosis:}

The diagnosis of PD is challenging, structured clinical diagnosis and at times autopsies are needed to look for lewy bodies [12-15]. In Patients with PD the diagnosis may be missed in about a quarter of patients [16, 17].Physicians usually look for signs and symptoms and if they are missing the diagnosis may go missed $[18,19]$.

\section{Symptoms:}

Three most common and obvious symptoms in patients with PD are tremor, rigidity, and bradykinesia. Tremor is the most common feature in tremor predominant PD [20-31]. Postural instability also occurs along with neural degeneration in the hypothalamic brainstem or peripheral nervous system [32-35]. Microganthia and hypophonia are also associated with PD [36-38].

\section{Treatment:}

Patients with PD are treated for their motor as well as non-motor symptoms [39, 40]. Therapies are identified to lower the disease progression slowing the neural damage $[41,42]$. A multidisciplinary team involving neurologists, primary care practitioners, nurses, physical therapists, social workers is used to diagnose PD. Nonpharmacological and pharmacological treatment is given to the patient. Jean-Martin Charcot and William Gowers were the first one to study Parkinsonism treatment .Treatment of Parkinsonian tremor with belladonna alkaloids was initiated [43].They work by maintaining the cholinergic/dopaminergic balance in the striatum and thereby improve Parkinsonism. Tyler stated that Charcot was the first one to use hyoscyamine in its treatment [44]. Hornykiewicz made dopamine in the year 1910 [45]. Whereas P. Holtz discovered the enzyme, dopa decarboxylase and proved that levodopa was turned to dopamine by it. Hornykiewicz studies dopamine, adrenaline and noradrenaline and stated that dopamine was quite different from the other two. In the year 1950 dopamine was localized in the brain striatum and a model was made showing the use of levodopa .Hence emerging theories came to show that dopamine loss caused PD [46, 47]. Levodopa causes the motor symptoms to improve making the gait better even the articulation and speech [48]. Subsequently trails were done confirming the use of levodopa in PD [4951]. Monoamine oxidase inhibitors and catechol- $O$-methyl transferase inhibitors were also discovered which acted as dopamine agonists .Amantadine was also discovered as an anti-Parkinsonian agent. In improves tremor and balance in PD patients [52] It causes inhibition of 
striatal synaptic dopamine reuptake so dopamine level increases in the synaptic cleft.

D-512, dopamine D2/3 receptor agonist: The new trends involves treating $\mathrm{PD}$ with selective dopamine- $\mathrm{D}_{2}$ and $-\mathrm{D}_{3}$ receptor agonists though it plays no role in handicapping the disease progression. Researchers in US have discovered a new drug D-512, having increased affinity for dopamine$D_{2}$ and $-D_{3}$ receptors with affect lasting thrice as long as ropinrole.

\section{Antioxidant properties:}

PD causes oxidative stress to damage brain tissue.D-512 has antioxidant properties [53].In an animal study, it was concluded that it carries a longer duration of action also helping in slowing disease progression. Also its antioxidant properties has a protective effect and decreases the oxidative stress in the brain [54].

\section{Placebo:}

Placebo-controlled trials also showed that placebo helped in treating PD [55]. The funding of federal grants for the specific study of placebo effects in Parkinson's disease is, in itself, of historical significance [56].

\section{Conclusion:}

Diagnosis of Parkinsonism disease is crucial and may at times go missed and at times it may overlap with dementia with Lewy bodies or Parkinsonian variants of multiple system atrophy. PD is a multisystem disorder. In time diagnosis and effective treatment can help slow and hamper disease progression improving the patient's outcome. However, this disease demands more clinical translational and prognostic research, identifying biomarkers that can help in early diagnosis of the disease and on developing future disease-modifying interventions.

\section{References:}

1. Parkinson J. (1817) An essay on the shaking palsy. Sherwood, Neely and Jones, London.

2. Langston JW (2006) The Parkinson's complex: Parkinsonism is just the tip of the iceberg. Ann Neurol 59(4):591-596.

3. Chaudhuri KR, Healy DG, Schapira AH, National Institute for Clinical Excellence (2006) Non-motor symptoms of Parkinson's disease: diagnosis and management. Lancet Neurol 5(3):235-245.

4. Martinez-Martin P, Rodriguez-Blazquez C, Kurtis MM, Chaudhuri KR, NMSS Validation Group (2011) The impact of non-motor symptoms on health-related quality of life of patients with Parkinson's disease. Mov Disord 26(3):399-406.

5. Schrag A, Sauerbier A, Chaudhuri KR (2015) New clinical trials for nonmotor manifestations of Parkinson's disease. Mov Disord 30(11):1490-1504.

6. Braak H, Del Tredici K, Rüb U, de Vos RA, Jansen Steur EN, Braak E (2003) Staging of brain pathology related to sporadic Parkinson's disease. Neurobiol Aging 24(2):197-211.

7. Klingelhoefer L, Reichmann H (2015) Pathogenesis of Parkinson disease - the gut-brain axis and environmental factors. Nat Rev Neurol 11(11):625-636.

8. Jellinger KA (2015) Neuropathobiology of non-motor symptoms in Parkinson disease. J Neural Transm 122:14291440.

9. Sauerbier A, Jenner P, Todorova A, Chaudhuri KR (2016) Non motor subtypes and Parkinson's disease. Parkinsonism Relat Disord 22(1):41-46.

10. De Lau LM, Giesbergen PC, de Rijk MC, Hofman A, Koudstaal PJ, Breteler MM. (2004) Incidence of parkinsonism and Parkinson disease in a general population: the Rotterdam Study. Neurology. 63(7):1240-1244.
11. De Rijk MC, Launer LJ, Berger K, Breteler MM, Dartigues JF, Baldereschi M, et al. (2000) Prevalence of Parkinson's disease in Europe. A collaborative study of population-based cohorts. Neurologic Diseases in the Elderly Research Group. Neurology. 54(11 Suppl 5):21-23.

12. Lapane KL, Fernandez HH, Friedman JH. (1999) Prevalence, clinical characteristics, and pharmacologic treatment of Parkinson's disease in residents in long-term care facilities. SAGE Study Group. Pharmacotherapy.19 (11):1321-1327.

13. Larsen JP. (1991) Parkinson's disease as a community health problem: study in Norwegian nursing homes. The Norwegian Study Group of Parkinson's disease in the Elderly. BMJ. 303(6805):741-743.

14. Mitchell SL, Kiely DK, Kiel DP, Lipsitz LA. (1996) The epidemiology, clinical characteristics, and natural history of older nursing home residents with a diagnosis of Parkinson's disease. J Am Geriatr Soc.44 (4):394-399.

15. Hughes AJ, Ben-Shlomo Y, Daniel SE, Lees AJ. (1992) What features improve the accuracy of clinical diagnosis in Parkinson's disease: a clinicopathologic study. Neurology. 42(6):1142-1146.

16. Hughes AJ, Daniel SE, Blankson S, Lees AJ. (1993) A clinicopathologic study of 100 cases of Parkinson's disease. Arch Neurol. 50(2):140-148.

17. Hughes AJ, Daniel SE, Lees AJ. (1993) The clinical features of Parkinson's disease in 100 histologically proven cases. Adv Neurol. 60:595-599.

18. Schrag A, Ben-Shlomo Y, Quinn N. (2002) How valid is the clinical diagnosis of Parkinson's disease in the community? J Neurol Neurosurg Psychiatry. 73(5):529-534.

19. Calne DB, Snow BJ, Lee C. (1992) Criteria for diagnosing Parkinson's disease. Ann Neurol. 32(Suppl 1):125-127.

20. Gelb DJ, Oliver E, Gilman S. (1999) Diagnostic criteria for Parkinson disease. Arch Neurol. 56(1):33-39.

21. Baumann CR. (2012) Epidemiology, diagnosis and differential diagnosis in Parkinson's disease tremor. Parkinsonism Relat Disord. 18(suppl 1):S90-S92.

22. Berardelli A, Wenning GK, Antonini A, et al. (2013) EFNS/MDS-ES recommendations for the diagnosis of Parkinson's disease. Eur J Neurology. 20:16-34.

23. Jankovic J. (2008) Parkinson's disease: clinical features and diagnosis. J Neurol Neurosurg Psychiatry. 79:368-376.

24. Reichmann H. (2010) Clinical criteria for the diagnosis of Parkinson's disease. Neurodegenerative Dis. 7:284-290.

25. Munhoz RP, Werneck LC, Teive HA. (2010) The differential diagnosis of parkinsonism: findings from a cohort of 1528 patients and a 10 years comparison in tertiary movement disorders clinics. Clin Neurol Neurosurg. 112:431-435.

26. Wickremaratchi MM, Knipe MD, Sastry BS, et al. The motor phenotype of Parkinson's disease in relation to age of onset. Mov Disord. 26:457-463.

27. Suchowersky O, Reich S, Perlmutter J, et al. (2006) Practice parameter: diagnosis and prognosis of new onset Parkinson disease (an evidence-based review): report of the Quality Standards Subcommittee of the American Academy of Neurology. Neurology. 66:968-975.

28. Jiménez MC, Vingerhoets FJ. (2012) Tremor revisited: treatment of PD tremor. Parkinsonism Relat Disord. 18(suppl 1):S93-S95.

29. Garcia Ruiz PJ, Catalán MJ, Fernández Carril JM. Initial motor symptoms of Parkinson disease. Neurologist. 17(suppl 1):S18 S20. 
30. Hallett M. (2012) Parkinson's disease tremor: pathophysiology. Parkinsonism Relat Disord. 18(suppl 1):S85S86.

31. Xia R, Mao ZH. (2012) Progression of motor symptoms in Parkinson's disease. Neurosci Bull. 28:39-48.

32. Kang P, Kloke J, Jain S. (2012) Olfactory dysfunction and parasympathetic dysautonomia in Parkinson's disease. Clin Auton Res. 22:161-166.

33. Doherty KM, van de Warrenburg BP, Peralta MC, et al. (2011) Postural deformities in Parkinson's disease. Lancet Neurol. 10:538-549.

34. Pfeiffer RF. (2012) Autonomic dysfunction in Parkinson's disease. Expert Rev Neurother. 12:697-706.

35. Jankovic J. (2008) Parkinson's disease: clinical features and diagnosis. J Neurol Neurosurg Psychiatry. 79:368-376.

36. Reichmann H. (2010) Clinical criteria for the diagnosis of Parkinson's disease. Neurodegenerative Dis. 7:284-290.

37. Maetzler W, Hausdorff JM. (2012) Motor signs in the prodromal phase of Parkinson's disease. Mov Disord. 27:627633.

38. Garcia Ruiz PJ, Catalán MJ, Fernández Carril JM. (2011) Initial motor symptoms of Parkinson disease. Neurologist. 17(suppl 1):S18-S20.

39. Simonson W, Hauser RA, Schapira AHV. (2007) Role of the pharmacist in the effective management of wearing-off in Parkinson's disease. Ann Pharmacother. 41:1842-1849.

40. Van der Marck MA, Bloem BR. (2014) How to organize multispecialty care for patients with Parkinson's disease. Parkinsonism Relat Disord. 20(suppl 1):S167-S173.

41. Fernandez HH. (2012) Updates in the medical management of Parkinson disease. Cleve Clin J Med. 79:28-35.

42. Uitti RJ. (2012) Treatment of Parkinson's disease: focus on quality of life issues. Parkinsonism Relat Disord. 18(suppl 1):S34-S36.

43. Ordenstein L. (1972) Sur la paralysie agitante et la sclérose en plaque généralisée. E Martinet, Paris.

44. Tyler K. (1992) A history of Parkinson's disease. In Handbook of Parkinson's disease (ed. Koller WC), pp. 1-34. Marcel Dekker, New York.
45. Hornykiewicz O. (2002) Dopamine miracle: From brain homogenate to dopamine replacement. Mov Disord 17: 501508.

46. Carlsson A, Lindqvist M, Magnusson T, Waldeck B. (1958) On the presence of 3-hydroxytyramine in brain. Science 127: 471.

47. Sano I, Gamo T, Kakimoto Y. (1959) Distribution of catechol compounds in human brain. Biochim Biophys Acta 32: 586587.

48. Birkmayer W, Hornykiewicz O. (1961) Der LDioxyphenylalanin-Effekt bei der Parkinson-Akinese. Wien Klin Wschr 73: 787-788.

49. Barbeau A. (1969) L-Dopa therapy in Parkinson's disease. Can Med Assoc J 101:59-68.

50. Yahr MD, Duvoisin RC, Schear MJ. (1969) Treatment of Parkinsonism with levodopa. Arch Neurol 21: 343-354.

51. Cotzias GC, Papavasiliou PS, Gellene R. (1969) Modification of Parkinsonism: Chronic treatment with L-dopa. N Engl J Med 280: 337-345.

52. Schwab RS, England AC, Poskanzer DC. (1969) Amantadine in the treatment of Parkinson's disease. JAMA 208: 1168-1170.

53. D-512, a novel dopamine D2/3 receptor agonist, demonstrates greater anti-Parkinsonian efficacy than ropinirole in Parkinsonian rats

54. David Lindenbach, Banibrata Das, Melissa M Conti, Samantha M Meadows, Aloke K Dutta, Christopher Bishop. (2017) D512, a novel dopamine D2 / D3 receptor agonist, demonstrates superior anti-parkinsonian efficacy over ropinirole in parkinsonian rats. British Journal of Pharmacology.

55. Goetz CG, Wuu J, McDermott MP, Adler CH, Fahn S, Freed CR, Hauser RA, Olanow WC, Shoulson I, Tandon PK, et al. (2008) Placebo response in Parkinson's disease: Comparisons among 11 trials covering medical and surgical interventions. Mov Disord 15: 690-699.

56. De la

FuenteFernandez R, Ruth TJ, Sossi V. (2001) Expectation and dopamine release: Mechanism of the placebo effect in Parkinson's disease. Science 293:1164-1166. 